\title{
SECONDARY SEXUAL CHARACTERS IN JAPANESE SEA-URCHINS
}

AUTHOR(S):

Tahara, Yutaka; Okada, Minoru; Kobayashi, Naomasa

\section{CITATION:}

Tahara, Yutaka ... [et al]. SECONDARY SEXUAL CHARACTERS IN JAPANESE SEA-URCHINS. PUBLICATIONS OF THE SETO MARINE BIOLOGICAL LABORATORY 1958, 7(1): 165-172

ISSUE DATE:

1958-12-20

URL:

http://hdl.handle.net/2433/174596

RIGHT: 


\title{
SECONDARY SEXUAL CHARACTERS IN JAPANESE SEA-URCHINS ${ }^{1)}$
}

\author{
YUTAKA TAHARA \\ Morphological Laboratory, Osaka Liberal Arts University \\ MINORU OKADA \\ Sakuranomiya Junior High School, Osaka City \\ and \\ NAOMASA KOBAYASHI \\ Zoological Institute, Kyoto University
}

With Plates VII-VIII and 5 Text-figures

\section{Introduction}

The sexual dimorphism in various forms of echinoids has hitherto been reported by many authors, as was excellently reviewed by E. B. Harvey (1956).

Independently from these discoveries of previous authors, TAHARA found the sexual difference of the genital papillae in Mespitia globulus, during his course of practical exercises of marine zoology for students in August, 1958, at the Seto Marine Biological Laboratory. Then, this observation was extended to other Japanese species of the sea urchin collected in the sea near the Laboratory, in cooperation with M. OKADA and N. Kobayashi. TaHARA studied the secondary sexual characters in Mespilia globulus, Toxopneustes pileolus and Tripneustes gratilla; OKADA in Echinostrephus aciculatus and Diadema setosum; and KoBAYASHI in Echinometera mathaei.

The authors are deeply indebted to Dr. Huzio UTinomi and Dr. Takasi Tokioka of the Seto Marine Biological Laboratory and wish to express their hearty thanks to them for offering us convenience and various helpful suggestions and also for referring them to literatures. We wish to express deep gratitude to Dr. O. Nakamura of the Osaka Liberal Arts University for reading the manuscript of this paper. Thanks are also due to Messrs. T. Yamamoto, S. URA and S. SAKAI of that Laboratory, and to Mr. R. OKuno of the Suma Aquarium, for their assistance in collecting materials.

1) Contributions from the Seto Marine Biological Laboratory, No. 320 .

Publ. Seto Mar. Biol. Lab., VII (1), 1958. (Article 6) 


\section{Observations}

The present observations were made on the following six species of the sea urchin: Mespilia globulus (LinNE)

Toxopneustes pileolus (LAMARCK)

Tripneustes gratilla (LINNE)

Echinometra mathaei (BLAINville)

Echinostrephus aciculatus A. AGAssiz

Diadema setosum (LESKE)

Freshly collected materials were observed under the binocular microscope with about ten magnifications and separated into two groups according to the shape of the genital papillae. Then the determination of the sex of each individual was made by the sexual elements taken at random from its gonads. From these results, it became clear that the genitial papilla in these species indicates a remarkable sexual dimorphism. Secondly, we investigated whether there exist other sexual characters or not. Though the characters examined varied with the species, the following were chosen in most cases: colour of spines, of tube feet, and of peristomeal membranes, the height of the tests (height-diameter ratios) and the size of the genital pores (diameter of the pores). The results obtained are presented here separately in each species.

\section{Mespilia globulus (LINNÊ).}

In this species, the male genital papilla protrudes on the body surface, forming a short cone. It rises to a height of about 110 micra. At the pointed end of the papilla, which is white in colour, there is an opening of the genital duct. Excepting this opening, the genital papilla is mostly colourless and semitransparent, but in some cases it bears minute dots, coloured dark olive green or reddish brown. On the other hand, the female genital papilla is flat and sunk below the body surface. Therefore, a clear, circular groove can be observed within the margin of the genital pore (Textfig. $1 \mathrm{~A}$ and $\mathrm{B}$; Pl. VII, figs. 1 and 2). There is no difference in colour between the genital papillae of both sexes.

The difference in the shape of the genital papilla mentioned above was confirmed by the microscopic observations of the sagittal sections. As is shown in Text-fig. 1, $\mathrm{C}$ and $\mathrm{D}$, the male genital papilla is taller than that of the female. Besides, in the male, the epidermis becomes thicker and cells of which it is composed are compact at the genital papilla; while in the female there is no thickening of the epidermis at the papilla. The wall of the male genital duct is also thicker than that of the female.

In addition to these differences between sexes, we saw individual variations in the following external characters: the colour of the spine, the interambulacral area, tube feet, the peristomeal membranes and the aboral disks; the height of the tests and the size of the genital pores. The last of these shows a clear sexual difference. For the measurement of the diameter, the genital pore of the first genital plate was arbitrarily chosen, but when it was abnormal - for example, when the first genital 


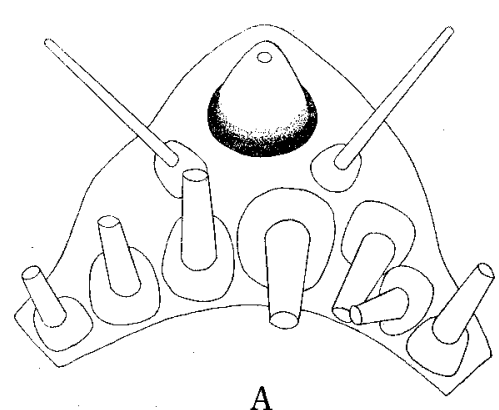

A

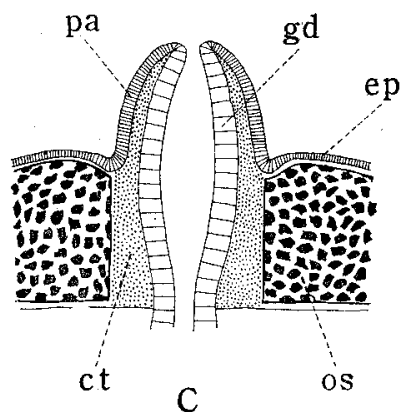

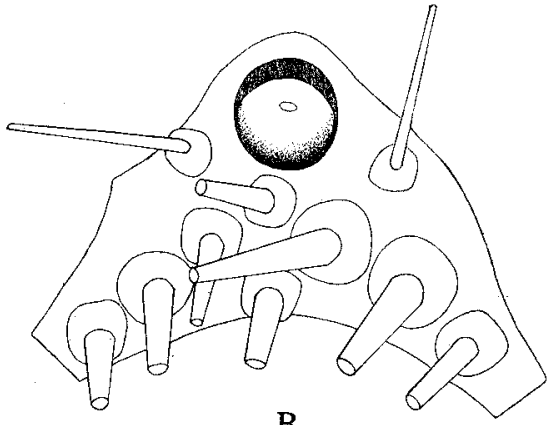

B

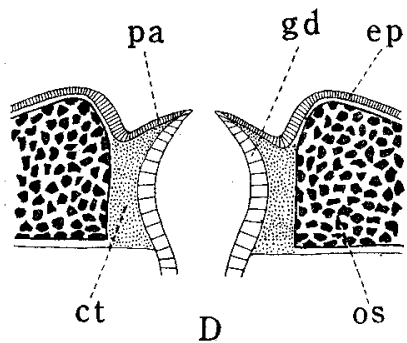

Text-fig. 1. Mespilia globulus. A. The fourth genital plate showing male genital papilla. B. The fifth genital plate showing female genital papilla. $\mathrm{C}$ and D. Diagrammatic sagittal sections of genital papillae of male

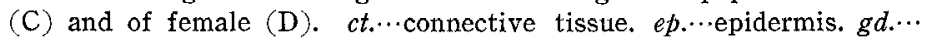
wall of genital duct. os. $\cdots$ ossicle of genital plate. pa. $\cdots$ wall of genital papilla.

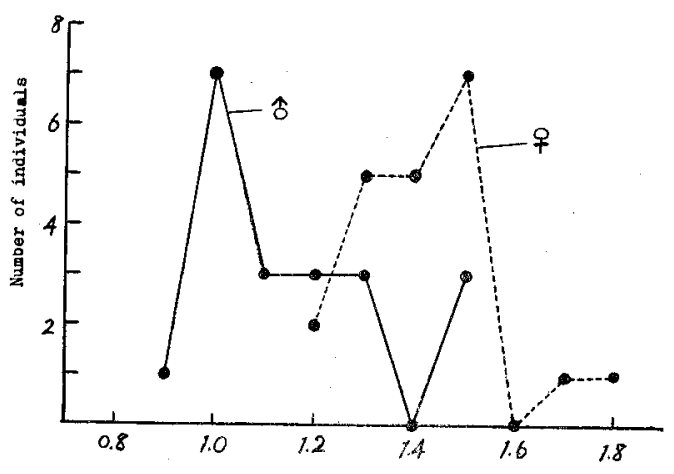

Fercentuge in the pore's dinmeter-test's diameter

Text-fig. 2. Frequency curves for both sexes. The mean values of diameter of pores to diameter of tests are 1.2 per cent in the male and 1.4 per cent in the female respectively. plate had two or more pores - the pore in another plate was chosen for measurement. Text-figure 2 shows the results. As can be seen in the graph, the size of the female genital pore is generally larger than that of the male. The other characters show no sexual differences.

Since the sexual difference of the genital papillae is very clear, we can distinguish the two sexes of the living animals with ease and accuracy. It is best to put the materials in sea-water and make observation under the binocular microscope of about ten magnifica-

tions, but with the help of the magnifying glass, we can distinguish the sexes with accuracy in the air. We used more than 100 individuals for observation during this 
summer, and were deceived in seven cases.

2. Toxopneustes pileolus (LAMARCK).

The genital papilla of the male is a short, stumpy, conical protuberance; while the female papilla is, in most cases; flat and sunk below the body surface, their shapes closely resembling those of Mespilia (Pl. VII, figs. 3 and 4). But, among the females, there are a few individuals of which the genital papilla considerably protrudes on the body surface. In the female, however, the circular groove at the base of the papilla being deeper than the male, it is not impossible to distinguish such females from males. We were deceived in four cases out of twenty-four $(15 \%)$. The genital papilla of both sexes is colourless and semitransparent, but in some cases it bears minute red or white dots near the base of the papilla.

Other external characters, such as the colour of spines, of valves of the globiferous pedicellariae and of peristomeal membranes, the height of the tests and the size of the genital pores were examined, and we could not detect any sexual differences in them.

\section{Tripneustes gratilla (LinNé).}

In this species, the male genital papilla is very long and measures about $3 \mathrm{~mm}$ in length in large individuals. It is almost equal to the length of the large globiferous pedicellariae surrounding the papilla and longer than the small spinules standing at the base of the papilla. It is penis-like in shape tapering off to the end. Excepting its pointed end, at which the genital duct opens, the papilla has the same colour as the skin, that is, it has minute purplish brown or orange coloured dots. On the other hand, the female genital papilla is stumpy, conical protuberance with obtuse end. It measures about $1.5 \mathrm{~mm}$ in length in large individuals. And it is shorter than both the stalk of the large globiferous pedicellariae and small spinules at the base of the papilla (Text-fig. 3 and Pl. VII, figs. 5 and 6). Its colour does not differ from the

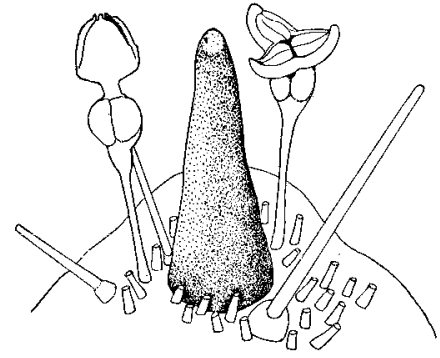

A

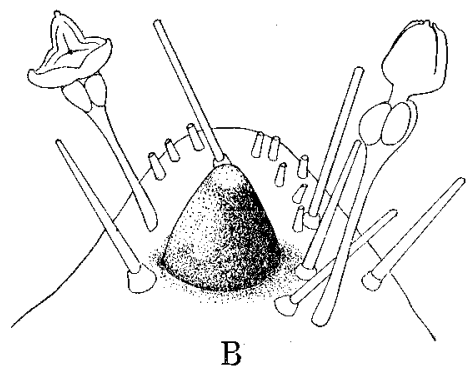

B. Genital

Text-fig. 3. Tripneustes gratilla.
papilla of female.

male papilla. Thus the genital papilla of this species is so large that one can distinguish the both sexes with the naked eye by finding out and observing the papilla on 
the madreporic plate. We examined fifty-seven individuals in all and were deceived only one case.

Moreover, the following external characters were examined: colour of the spines, tube feet, the peristomeal membrane; the height of the tests and size of the genital pores. All of these have no clear sexual differences.

\section{Echinometra mathaei (BLAINville).}

In the male, the genital papilla is long, slender and a penis-like projection with a pointed end. It measures about $1 \mathrm{~mm}$ in length in the longest one. As is shown in the photomicrographs (Pl. VIII, figs. 7 and 8), the length of the male genital papilla is in most cases more than half of that of the small spinules which are found near by the papilla. While in the female, the protuberance of the genital papilla is shorter than in the male. It is stumpy and has an obtuse end. As the photomicrograph shows, its length is always less than half of that of the neighbouring spinules. Its colour is dark purplish red in both sexes, except the white genital opening.

We also examined the colour of spines, of tube feet, of peristomeal membranes, the height of the tests and the size of the genital pores. But we could not find no clear sexual differences.

We comitted several errors - six cases out of forty-four (14\%) - in this species. They were caused due to the fact that the length of the male genital papillae was often less than half of that of the spinules standing near by the papillae.

\section{Echinostrephus aciculatus A. AgAssiz.}

The male genital papilla protrudes conically. And it has a pointed end. On the contrary, the female genital papilla is a short, obtuse-headed and wart-like protuberance (Text-fig. 4).

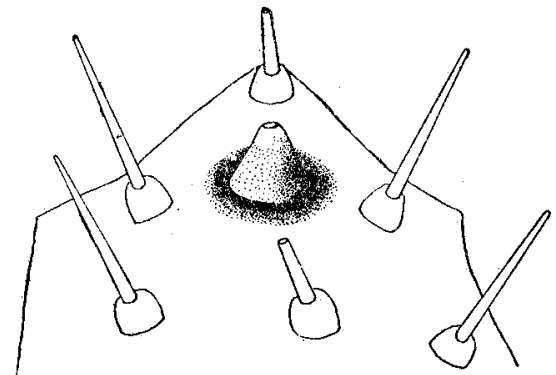

A

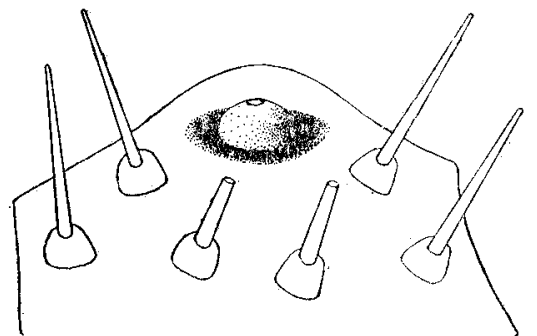

B

Text-fig. 4. Echinostrephus aciculatus. A. Genital papilla of male. B. Genital papilla of female.

Besides, the following individual variations were examined: the shape of the genital plates, the height of the tests and the size of the genital pores. Of these, the size of the genital pores shows a clear sexual difference. We examined eight cases in the male and fourteen in the female and obtained results that the mean values 
of diameter of pores to diameter of tests 1.2 per cent in the male and 1.4 per cent in the female respectively.

6. Diadema setosum (LESKE).

In the male, the genital papilla is longer than that in the female and protrudes on the body surface, inclining at about forty-five degrees towards proximo-distal direction of the genital plate. In the female the genital papilla is only a short, wartlike projection with an obtuse end (Text-fig. 5, A-D; Pl. VIII, figs. 9 and 10). Its colour is very dark purple excepting the tip of the papilla both in the male and the female.
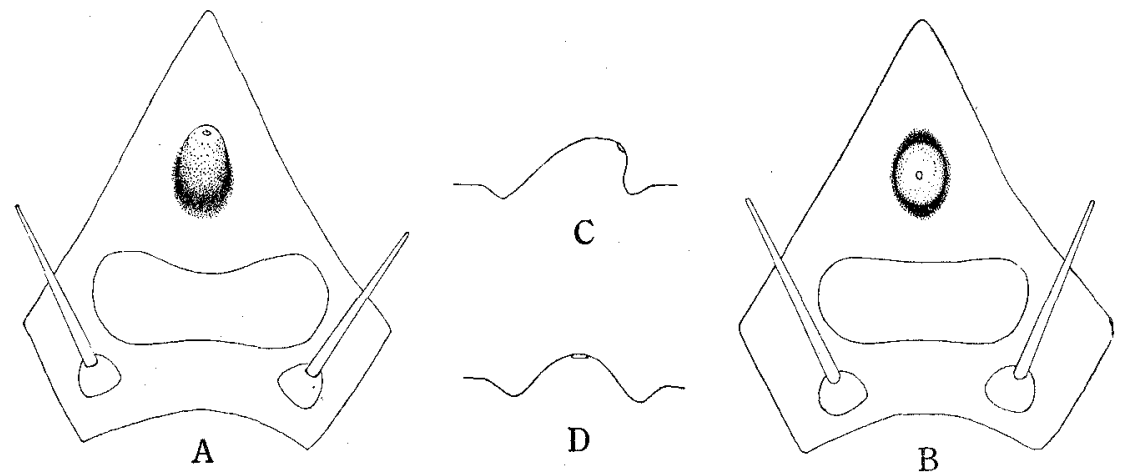

Text-fig. 5. Diadema setosum. A. The first genital plate showing male genital papilla. B. The first genital plate showing female genital papilla. C and D. Profiles of genital papillae of male (C) and of female (D).

Besides these, the colour of the interambulacral area, oral tube feet, the height of the tests and the size of the genital pores were examined. None of these shows clear sexual difference.

We recorded twenty-two cases in all in this species with no errors. If one observes the genital papilla on individuals with light coloured interambulacral areas, the determination of the sexes can easily be performed with the naked eye.

Besides these six species hitherto described, the shape of the genital papillae in Clypeaster japonicus was examined. In this species the genital papilla forms a considerably long tube with a pointed end. And we could not find any constant morphological differences between both sexes. Moreover, the studies are now in progress concerning the secondary sexual characters in other two species of the sea urchin: Hemicentrotus pulcherrimus and Anthocidaris crassispina and the results of which shall be reported at an early opportunity.

\section{Conclusions}

The sexual differences of the genital papillae in six species of the sea urchin described above may be roughly classified into the following two types: 
a) Mespilia type. The genital papillae of the male are short, conical protuberances, while those of the female are flat and sunk below the body surface. Mespilia globulus and Toxopneustes pileolus belong to this type.

b) Tripneustes type. The genital papillae of the male form remarkably long tubes, whereas those of the female are short and stumpy protuberances. Tripneustes gratilla, Echinometra mathaei, Echinostrephus aciculatus and Diadema setosum belong to this type.

In Europe, the sexual differences of the shape of the genital papillae have been found in several species of the sea urchin, and used for the purpose of separating two sexes in living animals. It is HAMANN (1887) who first discovered the sexual dimorphism in the genital papilla. He described that the female papilla in Echinocardium mediterraneum is thicker and shorter than the male. After that, MarX (1929) also found that in Psammechinus miliaris and Echinocyamus pussilus the shape and colour of the genital papillae are conspicuously different between both sexes. According to this author, in Ps. miliaris the male has short and stumpy genital papillae with terminal swellings, while the female has no papillae, its genital pores being covered with membranes of a light bluish colour. And in E. pussilus the genital papilla of the male is very long and penis-like, while in the female it is short and conical. It may be said, therefore, that he found two types of the sexual differences in genital papillae, namely, Ps. miliaris belonging to the Mespilia type and E. pussilus to the Tripneustes type. Recently, Swann (1954) observed the shape of the genital papillae in the following six European species of the sea urchin: Psammechinus miliaris, Ps. microtuberculatus, Echinus esculentus, Paracentrotus lividus, Sphaerechinus granularis and Arbacia lixula. He found that in all these species except Arbacia lixula the genital papillae show clear sexual differences. The genital pores of the male are borne on short papillae which show glistening white at its edge, while in the female the genital apertures are not borne on papillae but are more or less sunk below the level of the surroundings, and has no whitish colour. Accordingly, all these species may be grouped into the Mespilia type.

We have confirmed the findings of these authors in the Japanese species of the sea-urchin. Moreover, we have found by microscopic observations that the genital openings of the female in Mespilia globulus are borne on the flat papillae, and not on the membranes as was stated by Marx in European species of the sea urchin belonging to the Mespilia type (Text-fig. 1, C and D).

We have also found that in Mespilia globulus and Echinostrephus aciculatus the size of the genital pore of the female is generally larger than that of the male (Textfig. 2). This secondary sexual character has also been reported by MoRtensen (192851), IKedA (1931) and Tyler (1944). In his exhaustive works, Mortensen describes the sexual dimorphism of the genital pores in many species of echinoids, belonging to the genera Prionechinus, Caenopedina and Echinocyamus as well as to the families Cidariidae, Scutellidae and Neolampadidae. According to him, in these species the 
male genital pores are smaller as compared with the female and are more distally situated on the genital plates. IKEDA also reports that in Temnopleurus toreumaticus the male genital pore is in most cases rather smaller than the female and is situated almost at the center of the genital plate, while the female pore is shifted a little towards the periphery. TYLER also describes that in Lytechinus anamesus and $L$. pictus the genital pore of the female is larger than that of the male.

Besides these, there are many reports concerning the sexual differences in the height of the tests, colour of the bodies or of the tube feet on the oral side. We examined these characters in each of our species, but so far we have found no clear sexual differences by which we can distinguish sexes of living animals with certainty.

\section{REFERENCES}

BronN, H. G. 1904. Klassen und Ordnung des Thier-Reichs. Bd. II, Abt. 3, Buch IV, p. 1135. Leipzig.

HAMman, O. 1887. Beiträge zur Histologie der Echinodermen. Jena. Zeits. N., F., 14 (21), pp. 87266.

Harvey, E. B. 1956. The American Arbacia and other sea urchins. Chap. 7, pp. 47-48. Princeton. IKEDA, H. 1931. A biometric study of the sexual dimorphism and sex ratio in Temnopleurus toreumaticus (Klein). Annot. Zool. Jap., Vol. 13, pp. 233-242.

MARX, W. 1929. Über sekundäre Geschlechtsmerkmale bei Psammechinus miliaris und Echinocyamus pussilus. Zool. Anz., Bd. 80, pp. 331-335.

MORTENSEN, Th. 1928-1951. A monograph of the Echinoidea. Vols. I-V. Copenhagen.

SwanN, M. M. 1954. Secondary sex differences in five European species of sea-urchin. Pubbl. Stat. Zool. Napoli, Vol. 25, pp. 198-200.

Tyler, A. 1944. Sexual dimorphism in sea urchins. Anat. Rec., Vol. 81, p. 573.

UTrNomr, H. 1954. A check list of echinoids found in the Kii region. Publ. Seto Mar. Biol. Lab., Vol. 3 (3), pp. 339-358.

\section{EXPLANATION OF PLATES VII-VIII}

\section{Plate VII}

Fig. 1. Mespilia globulus; Male. Magnification about $17 \times$.

Fig. 2. M. globulus; Female. Magnification about $17 \times$.

Fig. 3. Toxopneustes pileolus; Male. Magnification about $17 \times$.

Fig. 4. T. pileolus; Female. Magnification about $17 \times$.

Fig. 5. Tripneustes gratilla; Male. Magnification about $7 \times$.

Fig. 6. T. gratilla; Female. Magnification about $7 \times$.

\section{Plate VIII}

Fig. 7. Echinometra mathaei; Male. Magnification about $14 \times$.

Fig. 8. E. mathaei; Female. Magnification about $14 \times$.

Fig. 9. Diadema setosum; Male. Magnification about $9 \times$.

Fig. 10. Diadema setosum; Female. Magnification about $9 \times$. 
Publ. Seto Mar. Biol. Lab., VII, 1 (1958)

PLATE VII
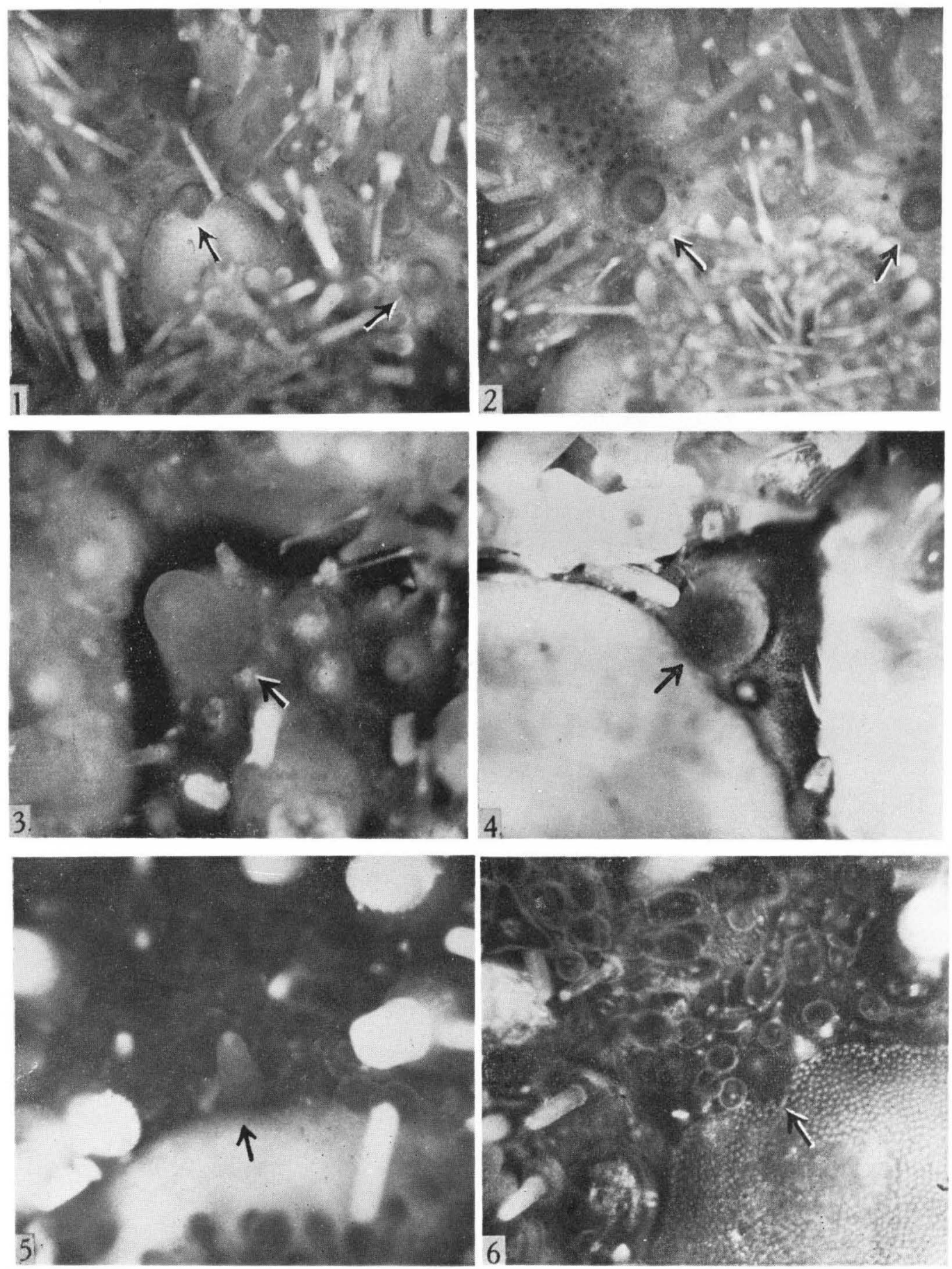

Y. Tahara et al.: Secondary Sexual Characters in Japanese Sea-urchins. 
Publ. Seto Mar. Biol. Lab., VII, 1 (1958)
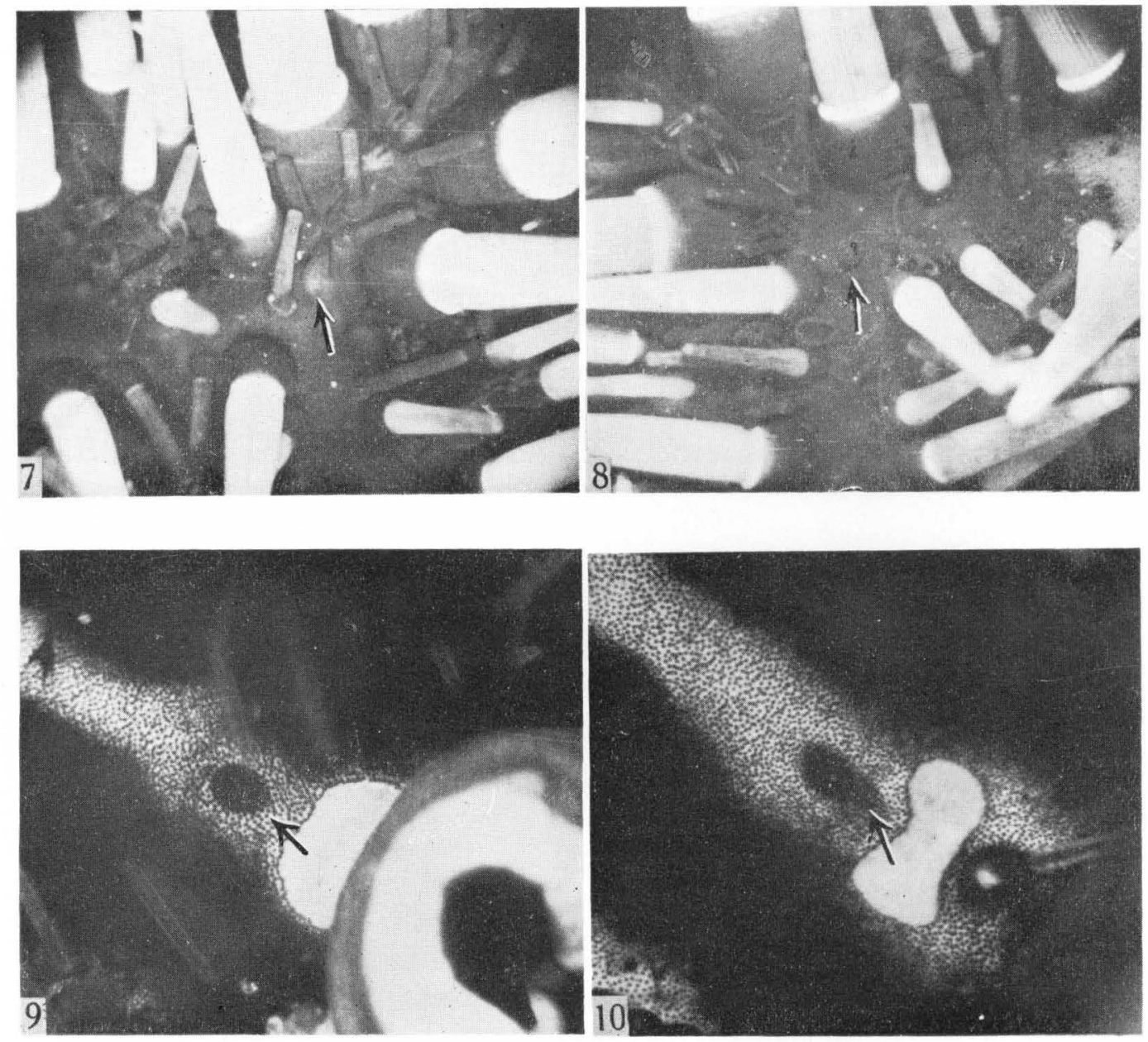

Y. Tahara et al.: Secondary Sexual Characters in Japanese Sea-urchins. 